\title{
Learning Assessment for Madrasah Teacher: Strengthening Islamic Psychosocial and Emotional Intelligence
}

\author{
Desi Sukenti 1 , Syahraini Tambak ${ }^{2}$, Ermalinda Siregar 3
}

DOI: 10.35445/alishlah.v13i1. 552

\begin{abstract}
Article Info
Abstract

Keywords: Islamic psychosocial emotional intelligence madrasah teacher learning assessment

This research focused on developing the learning assessment teacher of Madrasah Aliyah by strengthening Islamic psychosocial and emotional intelligence, using ex post facto research design and involving 297 Madrasah Aliyah teachers in 12 regencies/cities Riau Province, Indonesia. A questionnaire was made to measure Islamic psychosocial and emotional intelligence and measure learning assessment madrasah teachers. The data were analyzed using inferential statistics. The research results show that the gender levels of the madrasah aliyah teachers influence Islamic psychosocial but do not affect emotional intelligence and learning assessment. It confirms that male and female teachers do not have different emotional intelligence and teacher learning assessment, but Islamic psychosocial effects are affected. Madrasah teachers' teaching experience affects Islamic psychosocial, emotional intelligence, and learning assessment of madrasah aliyah teachers. This research shows that Islamic psychosocial contribution is "strong" in developing teacher learning assessments, while emotional intelligence has a "strong enough" effect. This research concludes that the learning assessment of madrasah teachers can be maximally developed by simultaneously mastering Islamic psychosocial and emotional intelligence in madrasah. This research has implications for the theory of "developing learning assessment for madrasah teachers" in developing the professionalism of madrasah teachers.
\end{abstract}

Kata kunci: psikososial Islam kecerdasan emosional guru madrasah penilaian pembelajaran

\begin{abstract}
Abstrak
Penelitian ini difokuskan pada pengembangan penilaian pembelajaran guru Madrasah Aliyah dengan penguatan kecerdasan psikososial dan emosional Islam. Menggunakan desain penelitian ex post facto dan melibatkan 297 guru Madrasah Aliyah di 12 kabupaten / kota di Provinsi Riau, Indonesia. Kuesioner dibuat untuk mengukur kecerdasan psikososial dan emosional Islam serta mengukur penilaian pembelajaran guru madrasah. Data dianalisis menggunakan statistik inferensial. Hasil penelitian bahwa tingkat jenis kelamin guru madrasah aliyah benar-benar berpengaruh terhadap psikososial islami, tetapi tidak berpengaruh terhadap kecerdasan emosional dan penilaian pembelajaran. Hal ini menegaskan bahwa guru laki-laki dan perempuan tidak memiliki kecerdasan emosional dan penilaian pembelajaran yang berbeda, tetapi ada pengaruhnya terhadap psikososial islami.
\end{abstract}

\footnotetext{
${ }^{1}$ Universitas Islam Riau, Pekanbaru, Indonesia

Email: desisukenti@edu.uir.ac.id

2 Universitas Islam Riau, Pekanbaru, Indonesia

Email: syahraini tambak@fis.uir.ac.id

3 Universitas Islam Riau, Pekanbaru, Indonesia

Email: siregarermalinda@student.uir.ac.id
} 
Pengalaman mengajar guru madrasah berpengaruh terhadap psikososial Islam, kecerdasan emosional, dan penilaian pembelajaran guru madrasah aliyah. Hasil penelitian menunjukkan bahwa kontribusi psikososial Islam adalah "kuat" dalam mengembangkan penilaian pembelajaran guru, sedangkan kecerdasan emosional memiliki pengaruh yang "cukup kuat". Hasil penelitian ini menyimpulkan bahwa asesmen pembelajaran guru madrasah dapat dikembangkan secara maksimal dengan secara simultan menguasai psikososial Islam dan kecerdasan emosional di madrasah. Hasil penelitian ini berimplikasi pada teori "pengembangan penilaian pembelajaran bagi guru madrasah" dalam mengembangkan profesionalisme guru madrasah.

\section{INTRODUCTION}

Learning assessment is an essential aspect of Islamic education because it is the key to success for teachers in bringing students to learn. The body of literature shows that the learning assessment activity is carried out not to look for mistakes or weaknesses based on evaluating an object or program being evaluated. However, the most important thing is knowing the effectiveness of an object that can run well and know the weaknesses that cause an object or program not to run well. So, it needs to be recommended to improve the weaknesses found (Allal, 2020; Divayana, 2017: Hamzah, Tambak, \& Tanjung, 2020). Learning assessments are conducted by teachers consisting of cognitive, affective, and psychomotor work together. In measuring the success of learning managed by teachers, measure student success in participating in learning activities, provide feedback for students and teachers, and self-evaluate teachers and schools to learn (Widiana, Jampel, and Nyoman, 2016).

Schools are required to develop reliable and credible student assessments to be the policies that surround them. Alimuddin's (2014) research revealed that schools that neglected assessment impacted students' potential creation and poor quality standards. Assessment is seen as the input obtained from the learning process that can determine the strengths and weaknesses of the various components contained in a learning process (McGrew et al., 2018). In assessing, educators need to be fair. This principle is followed by other principals so that the assessment can be done objectively. Because fair assessment is not influenced by familiarity factors, but is carried out as a whole, has clear criteria, is carried out in the right conditions and with the suitable instruments as well, to be able to show learning achievement students as they are.

So far, there have been several studies examining the assessment of teacher learning in various countries. Blanchet et al. (2016) researched in Canada concerning teacher competency assessment was strengthened along with occupational therapy with case study research. This study sees that the assessment of learning is still orthodox, so it needs improvement. Kuranishi \& Oyler's (2017) research in Malaysia on the success of teachers using learning assessments involving school principals and students with a qualitative research approach. This study sees that teacher learning assessment is still problematic in determining criteria, instrument validity, and follow-up assessment results. Bouzid (2017) revealed that the evaluation of learning carried out so far still tends to be on the cognitive aspect and is still low in making evaluation instruments given to students.

In Indonesia, there are several studies evaluating teacher learning in learning at school. Chairunisa's (2018) research in Palembang improves students' self-assessment ability by applying portfolio assessment with a class action research approach. This study sees that the assessment of student learning is deficient so it needs improvement. Masrul's (2015) study in Riau evaluated students' writing abilities in learning English with a descriptive approach. In addition, Agustina et al. (2018) research in Jambi on the analysis of authentic assessment based on the 2013 curriculum in schools with a qualitative approach. This study sees that the assessments that occur still need improvement, especially in the affective and psychomotor aspects. Another study was carried out by Astuti \& Darsinah (2018) in Surakarta on authentic curriculum-based assessment in 2013 in primary 
schools with a quantitative approach. This study sees that learning in primary schools is still not under the principles of assessment theoretically, so it requires new applications in overcoming it.

Although several studies have examined learning from various approaches and solutions, this is still a problem for teachers in madrasah schools. Teachers in most Indonesian madrasah schools still have difficulty applying learning assessments to students, especially in affective and psychomotor assessments (Sahrani, Mufidah, \& Rusnadi, 2019). While learning outcomes of learners must be carried out fairly and accountably (Colthorpe et al. 2018; Pisani, Borisova, \& Dowd, 2018; Elliott et al. 2018). Some madrasah teachers do not master the steps of learning evaluation (Aulia, Saputri, \& Albiansyah, 2021; Hendri et al. 2020) in Islamic education learning, so it affects the sincerity and sincerity of students' learning. It also appears in a variety of learning. Most madrasah teachers are less consistent in using evaluation steps (Huda, 2020; Xu \& Brown, 2016). This becomes an integral part of learning that must be implemented (Aqil, Setiawati, \& Kurniadi, 2020; Chairilsyah \& Kurnia, 2018). The madrasah teacher also seems to lack the mastery of the use of learning evaluations, especially making question instruments and a fair assessment system (Mardapi, \& Herawan, 2018).

To address this issue, solutions are required to improve all madrasah instructors' Islamic psychosocial and emotional intelligence in Indonesia. According to Anwar (2014), the Islamic psychosocial theory is a perspective that incorporates perceptions, motives, beliefs, and social interactions based on Islam in order to see a social issue as one that affects the characteristics of human behaviour in society. On the other side, Tambak \& Sukenti (2020) defined Islamic psychosocial by including Islamic-based perceptions, motives, beliefs, and social interactions to identify a social issue that affects individual behavior characteristics in society. Human behaviour must fulfil three requirements: (1) intrinsic Islam, which entails understanding the concept of the khalifah, understanding the concept of self-excellence, understanding the mission, establishing a mission, and developing insight, commitment, identity, intelligence, ideas, luck, creativity, obsession, and worship; and (2) external Islam, which entails understanding the concept of the khalifah, understanding the concept of self-excellence, understanding the mission, establishing a mission, and (2) social attitudes and perspectives, which include prejudice, mutual trust, mutual support, cooperation, openness, defensiveness, and withholding information (represented by a noncooperative and down appearance), living principles (represented by material and spiritual capital), experience (represented by positive and negative experiences), interests (represented by long-term and long-term interests), and wisdom based on experience.

While emotional intelligence in Goleman's (2010) theory about the ability of a person to manage oneself in dealing with other people around him by using all of his psychological potentials with self-control, passion, and persistence, self-motivation, and survival in frustration, controlling impulse and not exaggerating fun, maintaining mood and keeping stress burden not crippling the ability to think, empathize and pray. Emotional intelligence is a person's ability to receive, assess, manage, and control the emotions of himself and others around him. Emotional intelligence is a subset of social intelligence that involves monitoring social feelings that involve capability in others, sorting them all out, and using this information to guide thoughts and actions (Tambak, Ahmad, \& Sukenti, 2020).

This research examines the development of learning assessment for madrasah teachers by strengthening Islamic psychosocial and emotional intelligence. This study's purpose should be to determine the effect of Islamic behaviour and Islamic psychosocial in developing learning assessment for professional madrasah teachers. This research is a new thing and has never been found in madrasah education in Indonesia. Providing Islamic psychosocial and emotional intelligence is a new value in the development of madrasah teacher assessment, especially in improving teacher professionalism. This research has implications for the theory of "developing learning assessment for madrasah teachers" in developing the professionalism of madrasah teachers. The research questions were formulated; 1) the influence of Islamic psychosocial in developing madrasah teacher learning assessments in learning; 2) the influence of emotional intelligence in 
Al- Ishlah: Jurnal Pendidikan, June 2021, 13 (1), Pages 725-740

Desi Sukenti, Syahraini Tambak, Ermalinda Siregar

developing the assessment of madrasah teacher in learning, and 3) the influence of Islamic psychosocial and emotional intelligence in developing an assessment of madrasah teacher in madrasah learning.

\section{METHODS}

This research used ex-post facto (Sugiyono, 2014; Sudijono, 2014) to explore the understanding and feelings of Madrasah Aliyah teachers about Islamic psychosocial and emotional intelligence in developing madrasah teacher assessment in madrasah learning. It selected 297 madrasah teachers in of state Madrasahs Aliyah in all regencies/cities in Riau Province teaching Akidah Akhlak, Alquran Hadits, Fiqh, and Islamic Cultural History. A questionnaire was used as a data collection tool. The questionnaire is considered one of the right ways to get information from respondents (Creswell, 2015; Tuckman, 1999). It is a data collection technique performed by giving respondents a set of written questions with closed questions. The questionnaire is the easiest way to get information (Wiersma, 2000).

The questionnaire instruments were compiled into three parts: Islamic psychosocial scale instruments, emotional intelligence, and madrasah teacher assessment. The Islamic psychosocial instruments were arranged in the dimensions of intrinsic Islam, Islamic social attitudes, and the domain of da'wah and value. The emotional intelligence instruments were arranged in the dimensions of ability to receive, assess, manage, and control the emotions of himself and others around him. In contrast, professional madrasah teacher instruments were built on five dimensions: pedagogic competence, social competence, professional competence, personality competency, and leadership competence.

The research instruments were tested for validity by constructing validity (experts judgment) ( $p<0.05$ ), content validity (comparing the contents of the instrument with the theory), and external validity (comparing to find similarities) between the criteria on the instrument and empirical facts in the field (Sugiyono, 2014, Wiersma, 2000). In addition, while the reliability of the instrument (o.90) was tested by testing external: test-retest (stability), equivalent, and a combination of both, and internal: analyzing the consistency of the items on the instrument (Wiersma, 2000, Sugiyono, 2014).

Inference statistics were used as data analysis techniques and to test hypotheses that have been determined through ANOVA tests and linear regression ( $p$ <0.05) (Tuckman, 1999; Riduwan, 2014). The hypothesis of this research is "there is an influence of Islamic behaviour and Islamic psychosocial in developing professional madrasah teachers". The data were then analyzed using the Statistical Product Service Solution (SPSS) version 25.

\section{FINDINGS AND DISCUSSION}

\section{Profile and background of Islamic psychosocial madrasah teacher}

Islamic psychosocial of Madrasah Aliyah teachers in Riau Province is at a high stage. Table 1 shows that 237 or $79 \%$ of teachers with an average level of Islamic psychosocial of Madrasah Aliyah teachers in Riau Province (mean $=245.00, \mathrm{sd}=32.781$ ) are at a high level. It shows that Madrasah Aliyah teachers in Riau Province have owned and mastered emotional intelligence in educating students.

Table 1: Islamic Psychosocial Level

\begin{tabular}{lccccccc}
\hline Description & \multicolumn{9}{c}{ Low Stage } & \multicolumn{2}{c}{ High } & \multirow{2}{*}{ Stage } & Mean & Level \\
\cline { 2 - 6 } & $\mathbf{N}$ & $\mathbf{\%}$ & $\mathbf{N}$ & $\mathbf{\%}$ & & \\
\hline Islamic psychosocial & 60 & 20 & 237 & 80 & 245.00 & 32.781 & High \\
\hline
\end{tabular}

Thus, the construct of Islamic psychosocial has been possessed by madrasah teachers consisting of recognizing self-emotions, managing self-emotions, motivating themselves, recognizing the emotions of others, establishing relationships with others, applying the principle of 
star principle, angel principle, leadership principle, learning principle, vision principle, and well organize principle. This is under Herawaty's (2016) research, which states that madrasah teachers' Islamic psychosocial is highly competent to improve the teaching.

There are two things studied about the background of teachers, namely gender, and teaching experiences associated with Islamic psychosocial. By considering the Gender of Madrasah Aliyah teachers using the T-test, table 2 shows that it was conducted to compare the effect of gender of madrasah teachers on Islamic psychosocial in male and female conditions. There was a significant effect of age the madrasah aliyah teacher on Islamic psychosocial at the p>0.05 level for the three conditions $[\mathrm{T}(24.63,19.63=2.698, \mathrm{p}=0.021]$.

Table 2: The Differences in Islamic psychosocial by gender

\begin{tabular}{lccccc}
\hline Gender & $\mathrm{N}$ & $\mathrm{SD}$ & $\mathrm{Df}$ & $\mathrm{T}$ & $P$ \\
\hline Male & & & & & \\
Female & 176 & 24.636 & 297 & 2.698 & 0.021 \\
\hline
\end{tabular}

Taken together, these findings indicate that the gender of madrasah aliyah instructors does affect Islamic psychosocial development. Male madrasah aliyah instructors have more Islamic psychosocial skills throughout the teaching process than female madrasah aliyah teachers. The findings of this study are corroborated by Masdudi (2016), who found that men's and women's early childhood instructors exhibit variations in terms of Islamic psychosocial development. This demonstrates that male and female instructors have varying levels of emotional intelligence while conducting educational activities.

Table 3 shows differences in Islamic psychosocial of Madrasah Aliyah teachers in Riau Province in terms of teaching experience using the ANOVA test. Post hoc comparisons using the Tukey HSD test indicate that the mean score for the teacher's teaching experience was between 2130 years $(\mathrm{M}=262.35, \mathrm{SD}=34.89)$. It was significantly different from the teacher teaching experience is above 31 years condition $(\mathrm{M}=243.80, \mathrm{SD}=37.82)$ and teacher teaching experience between 1020 years condition $(\mathrm{M}=257.71, \mathrm{SD}=34.86)$. However, the teacher teaching experience under 10 years condition $(\mathrm{M}=245.91, \mathrm{SD}=29.24)$ did not significantly differ from the teacher teaching experience between 21-30 years, teacher teaching experience is above 31 years, and teacher teaching experience between 10-20 years condition.

Table 3: Differences in Islamic Psychosocial Based on Teaching Experience

\begin{tabular}{lcccc}
\hline Teaching Experience & N & Mean & SD & $P$ \\
\hline < 10 Years & & & & \\
10-20 Years & 74 & 245.91 & 29.242 & 0.007 \\
$21-30$ Years & 143 & 257.71 & 34.860 & \\
$>$ 31 Years & 75 & 262.35 & 34.893 & \\
\hline
\end{tabular}

These results suggest that the teachers' teaching experience between twenty-one to thirty years of the teaching experience period affects the Islamic psychosocial of madrasah aliyah teachers. Specifically, our results suggest that when the teacher a more extended teaching experience period between twenty-one to thirty years, they have high Islamic psychosocial that is useful in teaching. However, it should be noted that the senior teacher teaching experience level must be high in order between twenty-one to thirty years to see an effect. The teachers teaching experience under ten years, over thirty years, and between ten to twenty years does not appear to increase Islamic psychosocial significantly.

\section{Profile and background of emotional intelligence of madrasah teacher}

The emotional intelligence of Madrasah Aliyah teachers in Riau Province is at a high stage. Table 4 shows that 197 or $60 \%$ of teachers with an average level of Islamic psychosocial of Madrasah Aliyah teachers in Riau Province (mean $=255.00, \mathrm{sd}=33.781)$ are at a high level. It shows that 
Al- Ishlah: Jurnal Pendidikan, June 2021, 13 (1), Pages 725-740

Desi Sukenti, Syahraini Tambak, Ermalinda Siregar

Madrasah Aliyah teachers in Riau Province have owned and mastered emotional intelligence in educating students.

Table 4: Emotional Intelligence Level

\begin{tabular}{|c|c|c|c|c|c|c|c|}
\hline \multirow[t]{3}{*}{ Description } & \multicolumn{2}{|c|}{ Low Stage } & \multicolumn{2}{|c|}{ High } & \multirow{3}{*}{ Mean } & \multirow{3}{*}{ Sd } & \multirow{3}{*}{ Level } \\
\hline & & & & & & & \\
\hline & $\mathrm{N}$ & $\%$ & $\mathrm{~N}$ & $\%$ & & & \\
\hline Emotional intelligence & 100 & 34 & 197 & 66 & 255.00 & 33.781 & High \\
\hline
\end{tabular}

Thus, the construct of emotional intelligence has been possessed by madrasah teachers consisting of recognizing self-emotions, managing self-emotions, motivating themselves, recognizing the emotions of others, establishing relationships with others, applying the principle of star principle, angel principle, leadership principle, learning principle, vision principle, and well organize principle. It is under research conducted by Herawaty (2016), which states that teachers' emotional intelligence is high.

There are two things studied about the background of teachers, namely gender and teaching experiences associated with emotional intelligence. By considering the Gender of Madrasah Aliyah teachers using the T-test, table 5 shows that it was conducted to compare the effect of gender of madrasah teachers on emotional intelligence in male and female conditions. There was no significant effect of age of the madrasah aliyah teacher on emotional intelligence at the $\mathrm{p}>0.05$ level for the three conditions $[\mathrm{T}(27.69,18.63=-1.698, \mathrm{p}=0.091]$.

Table 5: The Differences in Emotional Intelligence by Gender

\begin{tabular}{lccccc}
\hline Gender & N & SD & Df & T & $P$ \\
\hline Male & 176 & 27.696 & 297 & -1.698 & 0.091 \\
Female & 121 & 18.632 & & & \\
\hline
\end{tabular}

Taken together, these results suggest that gender levels of the madrasah aliyah teachers do not affect emotional intelligence. This study's results are confirmed by Masdudi's (2016) research, which states that in terms of gender, men and women early childhood teachers do not have differences in emotional intelligence. It confirms that male and female teachers do not have different emotional intelligence in carrying out learning activities.

Using the ANOVA test, table 6 shows differences in the emotional intelligence of Madrasah Aliyah teachers in Riau Province in terms of teaching experience. Post hoc comparisons using the Tukey HSD test indicate that the mean score for the teacher teaching experience between 21-30 years $(\mathrm{M}=272.15, \mathrm{SD}=35.99)$. It was significantly different from the teacher teaching experience is above 31 years condition $(\mathrm{M}=247.80, \mathrm{SD}=38.42)$ and teacher teaching experience between 10-20 years condition $(M=247.91, S D=35.96)$. However, the teacher teaching experience under 10 years condition $(\mathrm{M}=245.81, \mathrm{SD}=30.21)$ did not significantly differ from the teacher teaching experience between 21-30 years. Therefore, teacher teaching experience is above 31 years, and teacher teaching experience is between 10-20 years.

Table 6: Differences in Emotional Intelligence Based on Teaching Experience

\begin{tabular}{|c|c|c|c|c|}
\hline Teaching Experience & $\mathrm{N}$ & Mean & SD & $P$ \\
\hline$<10$ Years & 74 & 245.81 & 30.212 & 0.004 \\
\hline 10-20 Years & 143 & 247.91 & $35 \cdot 960$ & \\
\hline 21-30 Years & 75 & 272.15 & 35.993 & \\
\hline$>31$ Years & 5 & 242.80 & 38.425 & \\
\hline
\end{tabular}

These results suggest that the teachers' teaching experience between twenty-one to thirty years of the teaching experience period affects the emotional intelligence of madrasah aliyah teachers. Specifically, our results suggest that when the teacher a more extended teaching experience period between twenty-one to thirty years, they have high emotional intelligence that is useful in teaching. However, it should be noted that the senior teacher teaching experience level must be high between 
twenty-one to thirty years to see an effect. The teachers' teaching experience under ten years, over thirty years, and between ten to twenty years does not significantly increase emotional intelligence.

\section{Profile and background of madrasah teacher assessment}

Table 7 shows that madrasah aliyah teacher assessment has a low level of the assessment learning process. The value indicates this (mean $=225 \cdot 71, \mathrm{sd}=25 \cdot 312$ ), which is low. There are 165 teachers, or $56 \%$, who have low teacher professionalism.

Table 7: The Level of Madrasah Teacher Learning Assessment

\begin{tabular}{lcccccccc}
\hline \multirow{2}{*}{ Variable } & \multicolumn{2}{c}{ Low Stage } & \multicolumn{2}{c}{$\begin{array}{c}\text { High } \\
\text { Stage }\end{array}$} & \multirow{2}{*}{ Mean } & Sd & Level \\
\cline { 2 - 6 } & $\mathrm{N}$ & $\%$ & $\mathrm{~N}$ & $\%$ & & \\
\cline { 2 - 6 } Learning Assessment & 165 & 56 & 132 & 44 & 225.71 & 25.312 & Low \\
\hline
\end{tabular}

Thus, $56 \%$ of madrasah aliyah teachers throughout Riau Province lack learning assessment in madrasah. This result is under research conducted by Asy'ari (2016), which found that 25\% of Madrasah Ibtidaiyah Unggulan in South Jakarta have low professionalism. The results of this study differ from the findings of a research conducted by Imron (2017) in which the teachers in Mojokerto have high professionalism in running the assessment of madrasah teachers.

As can be observed in Table 7, there are no disparities in learning evaluation between male and female Madrasah Aliyah instructors in Riau Province. Table 8 demonstrates that was performed to examine the impact of madrasah instructors' gender on their learning evaluation in male and female circumstances. There was no significant impact of teacherage on learning evaluation at the $\mathrm{p}>0.05$ level in any of the three circumstances [T $(24.53,19.73=-1.114, \mathrm{p}=0.266]$.

Table 8: Teacher Learning Assessment Differences Based on Gender

\begin{tabular}{lccccc}
\hline Gender & $\mathrm{N}$ & $\mathrm{SD}$ & $\mathrm{Df}$ & $\mathrm{T}$ & $P$ \\
\hline Male & 176 & 24.535 & 318 & -1.114 & 0.266 \\
Female & 121 & 19.733 & & & \\
\hline
\end{tabular}

These results suggest that gender levels of the madrasah aliyah teachers do not affect learning assessment. It is under research conducted by Mahmuda (2016) that male and female teachers have the same learning assessment in running the madrasah teacher profession. The results of this study also corroborate the results of research conducted by Amra (2016), which asserts that the learning assessment of male and female teachers do not have differences in the learning process. Judging from the background of age shows the difference of learning assessment of madrasah aliyah teachers in Riau Province.

Based on the length of teaching experience background, table 9, using the ANOVA test, illustrates the difference in teaching experiences of Madrasah Aliyah teachers in Riau Province. Post hoc comparisons using the Tukey HSD test indicate the mean score for the teaching experience between 21-31 years $(\mathrm{M}=233.20, \mathrm{SD}=21.34)$. It was significantly different from the teaching experience between $10-20$ years condition $(\mathrm{M}=213.24, \mathrm{SD}=23.35)$ and teaching experience above 31 years $(M=203.60, S D=18.56)$ madrasah teacher learning assessment. However, teaching experience under 10 years $(M=206.46, S D=21.24)$ did not significantly differ from the teaching duration above 31 years and teaching experience between 21-30 years on madrasah teacher learning assessment. 
Table 9: Learning Assessment Differences of Madrasah Aliyah Teachers Based on Teaching Experiences

\begin{tabular}{cccccc}
\hline Teaching Duration & $\mathrm{N}$ & Mean & SD & $F$ & $P$ \\
\hline < 10 Year & 74 & 206.46 & 21.242 & 22.195 & 0.000 \\
10-20 Year & 143 & 213.24 & 23.353 & & \\
21-30 Year & 75 & 233.20 & 21.348 & & \\
> 31 Year & 5 & 203.60 & 18.569 & & \\
\hline
\end{tabular}

These results suggest that the period experiences of teaching between twenty-one to thirty years levels do affect madrasah teacher learning assessment. Specifically, our results suggest that when the teacher has a teaching duration between twenty-one to thirty years, they have a high learning valuable assessment in teaching. However, it should be noted that the golden age of teaching level must be high for teaching duration between twenty-one to thirty years to see an effect. The teaching experiences between ten to twenty years, teaching experience under ten years, and teaching experience above thirty years do not appear to increase teacher assessment significantly.

\section{The Influence of Islamic Psychosocial on Learning Assessment of Madrasah Aliyah Teachers}

Table 10 illustrates the impact of emotional intelligence on the learning evaluation of Madrasah Aliyah instructors in Riau Province using simple linear regression. This is shown by the value $(\mathrm{F}=25.676)$ and the probability value (0.000) being less than the significance level (0.05) ( $P$ 0.05). Based on this instance, the study hypothesis that emotional intelligence affects the learning evaluation of Madrasah Aliyah instructors in Riau Province is approved.

Table 10: The Influence of Islamic Psychosocial on Learning Assessment of Madrasah Aliyah Teachers

\begin{tabular}{llccccc}
\hline & Model & Sum of Squares & Df & Mean Square & F & Sig. \\
\hline \multirow{2}{*}{1} & Regression & 14098.359 & 1 & 14098.359 & 25.676 & $.000^{\mathrm{b}}$ \\
& Residual & 174607.191 & 319 & 549.079 & & \\
& Total & 188705.550 & 320 & & & \\
\hline
\end{tabular}

a. Dependent Variable: Madrasah Teacher Learning Assessment

b. Predictors: (Constant), Islamic psychosocial

Additionally, table 11 demonstrates the impact of Islamic psychosocial education on the learning evaluation of Madrasah Aliyah instructors in Riau Province, which is 0.801 or 80.1 percent. The values of $(\mathrm{R}=0.895)$ and $(\mathrm{R}$ Square $=0.801)$ show this. The $\mathrm{R}$ Square value of $(0.801)$ or $(80.1$ percent ) indicates that emotional intelligence significantly impacts the learning evaluation of Madrasah Aliyah instructors in Riau Province.

Table 11: Magnitude of Islamic Psychosocial Influence on Assessment of Madrasah Teachers

\begin{tabular}{lccccc}
\hline Model & R & R Square & Adjusted R Square & $\begin{array}{c}\text { Std. Error of the } \\
\text { Estimate }\end{array}$ & Durbin-Watson \\
\hline 1 & $.895^{\mathrm{a}}$ & .801 & .672 & 23.432 & .888 \\
\hline
\end{tabular}

a. Dependent Variable: Madrasah Teacher Learning Assessment

b. Predictors: (Constant), Islamic psychosocial

Table 12 illustrates the effect of emotional intelligence on the learning evaluation of Madrasah Aliyah instructors in Riau Province using simple linear regression. This is shown by the value of $(\mathrm{F}=$ 24.776) and the probability value (0.000), both of which are less than the significance level (0.05) (P 0.05). Based on this instance, the study hypothesis that emotional intelligence affects the learning evaluation of Madrasah Aliyah instructors in Riau Province is approved. 
Table 12: The Influence of Emotional Intelligence on Learning Assessment of Madrasah Aliyah Teachers

\begin{tabular}{ccccccc}
\hline & Model & Sum of Squares & Df & Mean Square & F & Sig. \\
\hline \multirow{2}{*}{1} & Regression & 14098.359 & 1 & 14098.359 & 24.776 & .000 $^{\mathrm{b}}$ \\
& Residual & 174607.191 & 319 & 549.079 & & \\
\hline
\end{tabular}

a. Dependent Variable: Madrasah Teacher Learning Assessment

b. Predictors: (Constant), Emotional Intelligence

Furthermore, table 13 clearly illustrates the influence of emotional intelligence on the learning assessment of Madrasah Aliyah teachers in Riau Province of 0.075 or $7.5 \%$. This is indicated by the value of $(\mathrm{R}=0.237)$ and the value of $(\mathrm{R}$ Square $=0.075)$. Therefore, the $\mathrm{R}$ Square value of (0.075) or (7.5\%) describes that the effect of emotional intelligence on the professionalism of Madrasah Aliyah teachers in Riau Province is in the 'low' category.

Table 13: Magnitude of Emotional Intelligence Influence on Professionalism of Madrasah Aliyah Teachers

\begin{tabular}{cccccc}
\hline Model & $\mathrm{R}$ & R Square & Adjusted R Square & $\begin{array}{c}\text { Std. Error of the } \\
\text { Estimate }\end{array}$ & Durbin-Watson \\
\hline 1 & $.273^{\mathrm{a}}$ & .075 & .072 & 23.432 & .888 \\
\hline
\end{tabular}

a. Dependent Variable: Madrasah Teacher Learning Assessment

b. Predictors: (Constant), Emotional Intelligence

Table 14, using simple linear regression, shows an influence of Islamic psychosocial and emotional intelligence on the learning assessment of Madrasah Aliyah teachers in Riau Province. This is shown by the value of $(\mathrm{F}=27.376)$, and the probability value (0.00o) that is smaller than the value of significance (005) $(\mathrm{P}<0.05)$. Based on this case, the hypothesis of research stating that there is the influence of Islamic psychosocial and emotional intelligence on the learning assessment of Madrasah Aliyah teachers in Riau Province is accepted.

Table 14: The Influence of Islamic Psychosocial and Emotional Intelligence on Learning Assessment of Madrasah Aliyah Teachers

\begin{tabular}{ccccccc}
\hline & Model & Sum of Squares & Df & Mean Square & F & Sig. \\
\hline \multirow{2}{*}{1} & Regression & 14098.359 & 1 & 14098.359 & 27.376 & .000 $^{\text {b }}$ \\
& Residual & 174607.191 & 319 & 549.079 & & \\
\hline
\end{tabular}

a. Dependent Variable: Madrasah Teacher Learning Assessment

b. Predictors: (Constant), Islamic Psychosocial, Emotional Intelligence

Furthermore, table 15 clearly illustrates the influence of Islamic psychosocial and emotional intelligence on the learning assessment of Madrasah Aliyah teachers in Riau Province of 0.591 or $59,1 \%$. It is indicated by the value of $(\mathrm{R}=0.769)$. The value of $(\mathrm{R}$ Square $=0.591) \mathrm{R}$ Square value of (0.591) or (59.1\%) describes that the influence of Islamic psychosocial and emotional intelligence on the learning assessment of Madrasah Aliyah teachers in Riau Province is in the 'moderate' category.

Table 15: Magnitude of Islamic Psychosocial and Emotional Intelligence Influence on Professionalism of Madrasah Aliyah Teachers

\begin{tabular}{cccccc}
\hline Model & $\mathrm{R}$ & $\mathrm{R}$ Square & Adjusted R Square & $\begin{array}{c}\text { Std. Error of the } \\
\text { Estimate }\end{array}$ & Durbin-Watson \\
\hline 1 & $.769^{\mathrm{a}}$ & .591 & .172 & 23.432 & .888 \\
\hline
\end{tabular}

a. Dependent Variable: Madrasah Teacher Learning Assessment

b. Predictors: (Constant), Islamic Psychosocial, Emotional Intelligence

The study results illustrate that the gender levels of the madrasah aliyah teachers influence Islamic psychosocial, but on the other hand, really do not affect emotional intelligence and learning assessment. The results of this study are confirmed by a research of Masdudi (2016), which states 
Al- Ishlah: Jurnal Pendidikan, June 2021, 13 (1), Pages 725-740

Desi Sukenti, Syahraini Tambak, Ermalinda Siregar

that in terms of gender, men and women early childhood teachers do not have differences in terms of emotional intelligence. It confirms that male and female teachers do not have different emotional intelligence and madrasah teacher learning assessment in carrying out learning activities. However, there is an effect on Islamic psychosocial. The results of this study are under research conducted by Asyari (2016), who confirmed in the results of his research that there is no difference in emotional intelligence between the age of teachers in the learning process. It confirms that the age of an old or young teacher is not a determinant of emotional intelligence in the learning process.

Additionally, these findings indicate that the teaching length of teachers between the ages of twenty-one and thirty years has a significant effect on the Islamic psychosocial, emotional intelligence, and learning evaluation of madrasah aliyah instructors. Specifically, our findings indicate that when teachers have a longer teaching experience period of between twenty-one and thirty years, they have a higher level of Islamic psychosocial intelligence, emotional intelligence, and madrasah teacher learning assessment, all of which benefit teaching. However, it should be emphasized that the length of elderly teacher teaching must be between twenty-one and thirty years to observe an impact. Teachers with less than ten years of experience, teachers with more than thirty years of experience, and teachers with between ten and twenty years of experience do not seem to substantially improve Islamic psychosocial, emotional intelligence, or madrasah teacher learning evaluation.

These findings indicate that the learning assessment of madrasah teachers can be maximally developed by simultaneously mastering Islamic psychosocial and emotional intelligence in madrasah. Under the evaluation theory proposed by Richmond, Salazar \& Jones (2019), assessment of learning requires other factors for success, both self and external conditions. Evaluation is a statement of value based on the perspective of the appraiser's developer. When accreditation institutions prioritize specific teacher quality indices (for example, disposition, core practices) and the problem of scalability and value neutrality are ignored, those who play a leadership role in teacher preparation programs may find themselves without the time, resources, and expertise needed to respond to considering external demands (Thoma, et. al 2019; Tambak, et al. 2020; Sukenti, \& Tambak, 2019). The results may be a composite of not practical judgments for evaluative or learning purposes and may not reflect program or institutional values.

The learning assessment is related to a student's fate whether or not, graduated or not, which is strongly influenced by the teacher's credibility and professionalism in assessing-learning assessment influences the position and quality of the school so that personality and social skills are needed to maximize it comprehensively (Allal, 2020; Cerezo et al. 2020; Friederika, Hains-Wesson, \& Karen, 2017; Ahmad, Tambak, \& Hasanah, 2018). Then the Islamic psychosocial and emotional intelligence are very appropriate to be held by madrasah teachers to assess students' learning correctly, reasonably, validly, accountable, and trusted. These are efforts to overcome the going challenges faced by madrasah teachers-how to develop learning assessments that are informative, measurable, and accepted by the majority of experts in this field.

Suppose at the same time, Islamic psychosocial and personality competencies are very high, affecting the assessment of Indonesian language learning. In that case, the findings of this study predict that each has a different effect. Islamic psychosocial is predicted to influence significantly emotional intelligence in developing an assessment of madrasah teachers in aliyah madrasah. Islamic psychosocial theory contains a person's abilities, both individual, social, faith, morals, and self-organization, partly contained in personality competence (Rahmawati, Imaduddin, Haqiqi, Fikri, Fawaida, Prasetyo, \& Faikhamta, 2020; Zaid et al. 2020). Islamic psychosocial theory includes perceptions, motivations, beliefs, and social interactions based on Islam to see a social problem that will affect the attributes of individual behavior in society. Human behavior must fulfill three things, namely: 1) the intrinsic Islam that is knowing the concept of the caliph, knowing the concept of selfexcellence, knowing the mission, building a mission, creating insight, commitment, identity, intelligence, ideals, luck, creativity, obsession, and worship; 2) social attitudes and perspectives 
which include prejudice, mutual trust, mutual support, cooperation, openness, defensive, closed, withholding information (consisting of non-cooperative and down appearance), living principles (consisting of material capital and spiritual capital), experience (consisting of positive and negative), interests (consisting of long-term and long-term), wisdom based on the rules of Allah SWT and His Messenger, comparison (high value standards, low value standards, objective and subjective), and literature (consisting of religion, philosophy and science); and 3) da'wah and self-valuesas true faith and confidence, istikhlas, ihsan (tawajuh), ihtisab, mujahadah nafsi, sure in the sentence of thayyibah, special prayer, knowledge of ma'azikir, ikromul muslimin, tashihunniyat, and da'wah wa al-tabligh (Tambak \& Sukenti, 2020; Sukenti, Tambak, \& Charlina, 2020).

Bous et al. (2019) research findings show that psychosocial possessed by a person dramatically influences adaptation to the environment. Social factors are predicted to build relationships and attitudes of someone in implementing something new. Perceptions, attitudes, and personality factors are the main determinants of someone acting with high mobility. This is confirmed by the research findings of Preś, Kurpisz \& Pełka-Wysiecka (2018) and Tambak et al. (2018) psychosocial factors associated with emotional reactions of gratitude and forms of expressing gratitude are closely related to the development of human personality. The level of gratitude is positively correlated with selfesteem, emotional intelligence, and readiness to help people-both generous and others. Self-esteem, emotional intelligence, and readiness to help others are essential aspects of the teacher's social psychology to develop maximum professionalism.

Karada's (2019) research reveals that instructor grades or achievement assessments are used to evaluate the academic results of the course. Psychosocial factors have a significant impact on student achievement when a fair assessment is used. The findings indicated that students' participation in extracurricular activities improved their relationships with peers and lecturers, boosted their enthusiasm to attend classes, and assisted them in managing their stress. Teachers' knowledge of psychosocial development enables them to assess pupils' talents in social relations and psychology more accurately. This is further backed by Tjalla's (2020) research. His findings on the psychosocial ability of teachers are recommended to the government to enable school collaboration with universities to produce teacher assessments in schools.

Although the Islamic psychosocial is predicted to influence significantly emotional intelligence in developing madrasah teacher learning assessment, the level is not too much different. It is not also ignoring emotional intelligence because its influence is predicted to be under Islamic psychosocial. However, both of them equally contributed significantly to developing the assessment of madrasah teachers in madrasah school. The results of this study are also supported by research findings from Utami et al. (2019) that the development of professional teachers can be done by increasing attitudes of social psychology and good self-perception about the environment. Emotional intelligence in developing assessment in the findings of Hamid, Suriansyah, \& Ngadimun (2019) requires special handling from the government to develop madrasah teacher learning assessment.

The study results illustrate that emotional intelligence can influence the learning assessment of Madrasah Aliyah teachers in Riau Province. Thus, the construct of emotional intelligence must be owned by Madrasah Aliyah teachers so that they are professional in carrying out their occupation. Therefore, the construct of emotional intelligence, as proposed by Tambak \& Sukenti (2019), is the ability to manage the emotions of self, to recognize the emotions of self, to motivate oneself, to recognize the emotions of others, and to connect with others, which Madrasah Aliyah teachers in Riau Province must own. The importance of emotional intelligence possessed by teachers is also reflected in Puspitacandri's (2020) opinion that one who can accept, judge, manage, and control the emotions of himself and others around him will be successful in every work.

The results of this study are also under research conducted by Kustyarini (2020), which asserted that the teachers who have emotional intelligence could develop learners to recognize themselves and others so that they can raise their self-confidence to have high independence in the learning process. The emotional intelligence possessed by the teacher can develop the individual 
academic abilities and the development of social aspects, as well as build team collaboration and good learning interaction with teachers and learners (Noer, Tambak \& Rahman, 2017, Tambak \& Sukenti, 2019). Therefore, emotional intelligence will create morality and then produce a good personality that can be improving the learning assessment in the learning process (Supriyanto, Ekowati \& Masyhuri, 2019; Droppert et al., 2019; Gebregergis, Huang \& Hong, 2020).

The results of this study are also in line with the research of Lee, Kwon, \& Richards (2019) on the influence of emotional intelligence on teacher performance, in which the samples were the teachers who taught in elementary schools. This study looked at respondents' backgrounds, example, gender, age, status, length of teaching, certification status, duration of work, last education, and occupation. This study proved that emotional intelligence partially affects the performance of teachers in the dimension of social skills. In contrast, the dimensions of self-knowledge, self-control, self-motivation, and empathy do not partially affect teachers' performance. While the dimensions of social skills, self-knowledge, self-control, self-motivation, and empathy collectively influence teachers' performance.

Asyari (2016), in his research, confirmed that emotional intelligence affects the creativity of teachers in teaching. In the learning process, teachers must be professional in terms of attitude and creative in forming the patterns of interaction that can encourage students to learn. The formation of attitude and creativity requires emotional intelligence, which can influence the thoughts, feelings, responses and manipulate the information in a harmonious relationship with students. This study is also in line with research conducted by Paskaran \& Azman (2020) that emotional intelligence affects teachers' performance. Emotional intelligence and teacher participation in scientific forums directly impact the teachers' self-efficacy, emotional intelligence, and teacher participation in scientific forums. Self-efficacy and motivation influence a teacher's performance.

Strengthening the emotional intelligence of madrasah teachers will make teaching professionalism and mastery of teaching students higher. The results of Lonto, Pasandaran \& Pangalila (2018) study revealed that social-emotional learning is part of emotional intelligence, which in practice is another way to focus on the measurement and remediation of individual deficits rather than a way to redirect educators' focus to the context of classrooms and school relationships. However, social, emotional learning guarantees to foster increased achievement and equity in education may not be realized unless there is more work to bed one to connect ideals with practices and address the political and cultural assumptions built into contemporary approaches.

\section{CONCLUSION}

The study results illustrate that the gender levels of the madrasah aliyah teachers really study results illustrate that the gender levels of the madrasah aliyah teachers influence Islamic psychosocial, but on the other hand, really do not affect emotional intelligence and learning assessment. It confirms that male and female teachers do not have different emotional intelligence and madrasah teacher learning assessment in carrying out learning activities. However, there is an effect of Islamic psychosocial. These results also suggest that the teachers teaching duration between twenty-one to thirty years levels of the period of teaching experience do affect Islamic psychosocial, emotional intelligence, and learning assessment of madrasah aliyah teachers. Specifically, our results suggest that when the teacher a more extended teaching experience period between twentyone to thirty years, they have high Islamic psychosocial, emotional intelligence, and madrasah teacher learning assessment that is useful in teaching. However, it should be noted that the senior teacher teaching duration level must be high between twenty-one to thirty years to see an effect. The teachers' teaching duration under ten years, over thirty years, and between ten to twenty years levels do not appear to increase Islamic psychosocial, emotional intelligence significantly, and madrasah teacher learning assessment. This research shows that Islamic psychosocial contribution is "strong" in developing teacher learning assessments, while emotional intelligence has a "strong enough" effect. This research concludes that the learning assessment of madrasah teachers can be maximally developed by simultaneously mastering Islamic psychosocial and emotional intelligence in 
madrasah. This research has implications for the theory of "developing learning assessment for madrasah teachers" in the learning process in Indonesian madrasah.

\section{REFERENCES}

Agustina, M., Suraida, Alfian, \& Syefrinando, B. (2018). Authentic Assessment Analysis Based on The Curriculum 2013 at SMP Negeri 7 Muaro Jambi. Jurnal Biodik. 4(2), 135-144. https://doi.org/10.22437/bio.v4i2.6127.

Ahmad, M. Y., Tambak, S., \& Hasanah, U. (2018). Pengaruh Kecerdasan Emosional terhadap Penyesuaian Diri Mahasiswa Thailand. Al-Hikmah: Jurnal Agama dan Ilmu Pengetahuan, 15(2), 16-30. https://doi.org/10.25299/al-hikmah:jaip.2018.vol15(2).2374.

Alimuddin. (2014). Assessment in the 2013 Curriculum. Prosiding Seminar Nasional Pendidikan Karakter, Universitas Riau, 1(1), 23-33. https://doi.org/10.22437/bio.v4i2.6127.

Allal, L. (2020). Assessment and the co-regulation of learning in the classroom. Assessment in $\begin{array}{llll}\text { Education: } \quad \text { Principles, } \quad \text { Policy \& } \quad \text { Practice, } & \text { 27(4), } 332-349 .\end{array}$ https://doi.org/10.1080/0969594X.2019.1609411

Amra, A. (2016). Profesionalisme Guru dalam Meningkatkan Mutu Pendidikan di Era Teknologi Informasi. Jurnal Pendidikan 14(2): 154-162. http://dx.doi.org/10.31958/jt.v14i2.210.

Anwar, K. (2014). The mental-cognitive effects of Islam and the practice of the Sunnah through the intermediary of Islam psychosocial and Kendiri of Estim of self-attitude in self-control in adolescent practice problems, Disertasi Universiti Kebangsaan Malaysia.

Aqil, D. I., Setiawati, N. A., \& Kurniadi, F. (2020). The Implication Of Teacher Professionalism Improvement And Learning Evaluation Techniques Toward Madrasah Teacher Performance. $\begin{array}{lll}\text { Tarbiyah: Jurnal Ilmiah } \quad \text { Kependidikan, } & \text { 9(2), }\end{array}$ http://dx.doi.org/10.18592/tarbiyah.v9i2.3651

Astuti, S. \& Darsinah. (2018). Authentic assessment based on the 2013 curriculum at SD Negeri 16 Mangkubumen Kidul Surakarta. Jurnal Managemen Pendidikan. 13(2), 165-174. https://doi.org/10.23917/jmp.v13i2.7484.

Asy'ari, H. (2016). Profil Profesionalisme Guru Madrasah Ibtidaiyah Unggulan di Jakarta Selatan. Tarbiya: Journal of Education in Moslem Society 1(1), 51-60. https://doi.org/10.15408/tjems.vii1.1110

Aulia, N. Q., Saputri, N. I., \& Albiansyah, A. (2021). Teacher'assessment of young language learners in speaking skill. Lingua: Jurnal Ilmiah, 17(1), 47-61. https://doi.org/10.35962/lingua.v17i1.63

Blanchet, M., Huynh, T., Giroux, D. \& Bottari, C. (2016). L'évaluation en ergothérapie pour contribuer à documenter l'aptitude: étude de CAS: Contribution of occupational therapy to the assessment of competence: A case study," Canadian Journal of Occupational Therapy, 83(3), 154-165. https://doi.org/10.1177/o0o8417416644272.

Bouzid, H. A. (2017). An Evaluation of Selected Moroccan Elt Textbooks: A Standards-Based Approach Perspective. Indonesian Journal of Applied Linguistics. 7(1), 229-238. https://doi.org/10.17509/ijal.v7i1.6879.

Bous, R. M., Hazen, R.A., Irene Baus, J. Martin Palomo, Anand Kumar \& Manish Valiathan. (2019). Psychosocial Adjustments among Adolescents with Craniofacial Conditions and the Influence of Social Factors: A Multi-Informant Study. The Cleft Palate-Craniofacial Journal. 57(5), 624636. https://doi.org/10.1177/1055665619888308.

Cerezo, R., Bogarín, A., Esteban, M., \& Romero, C. (2020). Process mining for self-regulated learning assessment in e-learning. Journal of Computing in Higher Education, 32(1), 74-88. http://dx.doi.org/10.1007/s12528-019-09225-y.

Chairunisa, E. D. (2018). Portfolio assessment in improving student self-assessment skills (in Bahasa), Kalpataru, Jurnal Sejarah dan Pembelajaran Sejarah 4(1), 83-88. http://dx.doi.org/10.31851/kalpataru.v4i1.2442.

Chairilsyah, D., \& Kurnia, R. (2018). Teacher Assessment to School Readiness on the 5-6 Year-Old Children in State Kindergarten in Pekanbaru (Motoric Physical, Social Emotional, Moral, Language, and Cognitive Aspect). Journal of Educational Sciences, 2(2), 74-82. http://dx.doi.org/10.31258/jes.2.2.p.74-82.

Creswell, J. (2015). Educational Research: Planning, Conducting, and Evaluating Quantitative and Qualitative. Oxford: Pearson Education, Inc. 
Al- Ishlah: Jurnal Pendidikan, June 2021, 13 (1), Pages 725-740

Desi Sukenti, Syahraini Tambak, Ermalinda Siregar

Colthorpe, K., Sharifirad, T., Ainscough, L., Anderson, S., \& Zimbardi, K. (2018). Prompting undergraduate students' metacognition of learning: implementing 'meta-learning'assessment tasks in the biomedical sciences. Assessment \& Evaluation in Higher Education, 43(2), 272285. https://doi.org/10.1080/02602938.2017.1334872.

Divayana, D. (2017). Evaluation of E-Learning Utilization Using the Cse-Ucla Model. Cakrawala Pendidikan: Jurnal Ilmiah Pendidikan. 36(2), 280-289.

Droppert, K., Downey, L., Lomas, J., Bunnett, E. R., Simmons, N., Wheaton, A., \& Stough, C. (2019). Differentiating the contributions of emotional intelligence and resilience on adolescent male scholastic performance. Personality and Individual Differences, 145, 75-81.

Elliott, S. N., Davies, M. D., Frey, J. R., Gresham, F., \& Cooper, G. (2018). Development and initial validation of a social emotional learning assessment for universal screening. Journal of Applied Developmental https://doi.org/10.1016/j.appdev.2017.06.002.

Psychology, 55,

39-51.

Friederika, K., Hains-Wesson, R., \& Karen, Y. (2017). Practical Typology of Authentic WorkIntegrated Learning Activities and Assessments, Asia-Pacific Journal of Cooperative Education 18(2), 153-165. https://www.proquest.com/docview/2231183357?pqorigsite $=$ gscholar\&fromopenview $=$ true.

Gebregergis, W. T., Huang, F., \& Hong, J. (2020). The impact of emotional intelligence on depression among international students studying in China: the mediating effect of acculturative stress. International Journal of Intercultural Relations, 79, 82-93. http://dx.doi.org/10.31851/kalpataru.v4i1.2442.

Hamid, P. A., Suriansyah, A., \& Ngadimun, N. (2019). The relationship between interpersonal and emotional intelligence on teacher performance. Journal of K6 Education and Management, 2(1), 71-77. http://dx.doi.org/10.11594/jk6em.02.01.10

Hamzah, D. S., Tambak, S., \& Tanjung, W. U. (2020). Overcoming self-confidence of Islamic religious education students: The influence of personal learning model. Journal of Education and Learning (EduLearn), 14(4), 582-589. https://doi.org/10.11591/edulearn.v14i4.16759.

Hendri, Z., Kurniawati, K., Umasih, U., \& Jufrianis, J. (2020). Implementation of Authentic Assessment in Historical Learning in Madrasah Aliyah Negeri (MAN) Pekanbaru City. IJEBD (International Journal Of Entrepreneurship And Business Development), 3(4), 439-444. https://doi.org/10.29138/ijebd.v3i4.1203

Herawaty, D. (2016). Pengaruh Kecerdasan Emosional, Partisipiasi Guru dalam Forum Ilmiah, Keyakinan Diri (Self Efficacy), dan Motivasi Kerja terhadap Kinerja Guru Matetmatika. Jurnal Review Pembelajaran Matematika 1(1): 71-85. https://doi.org/10.15642/jrpm.2016.1.1.71-85.

Huda, I. (2020). Implementation of Authentic Assessment in Thematic Learning 2013 Curriculum at Madrasah Ibtidaiyah. Journal of K6 Education and Management, 3(4), 456-466. https://doi.org/10.11594/jk6em.03.04.05

Imron, M. (2017). Peningkatan Profesionalisme Guru melalui Pengawas Madrasah. Modeling: $\begin{array}{lllll}\text { Jurnal Program } & \text { Studi } & \text { PGMI } & \text { 4(1): } & \text { 19-38. }\end{array}$ http://www.jurnal.stitnualhikmah.ac.id/index.php/modeling/article/view/112.

Karadağ, S. (2019). Psychosocial Achievements of Social Studies Teacher Candidates in out door Geography CoursesCourses. Review of International Geographical Education Online. 9(3), 663-677. https://doi.org/10.33403/rigeo.580824.

Kuranishi, A. \& Oyler, C. (2017). I failed the ed TPA. Teacher Education and Special Education. 40(4), 299-313. https://doi.org/10.1177/o888406417730111.

Kustyarini, K. (2020). Self-Efficacy and Emotional Quotient in Mediating Active Learning Effect on Students' Learning Outcome. International Journal of Instruction, 13(2), 663-676. https://doi.org/10.29333/iji.2020.13245a.

Lee, Y. H., Kwon, H. H., \& Richards, K. A. R. (2019). Emotional intelligence, unpleasant emotions, emotional exhaustion, and job satisfaction in physical education teaching. Journal of Teaching in Physical Education, 38(3), 262-270. https://doi.org/10.1123/jtpe.2018-0177.

Lonto, A. L., Pasandaran, S., \& Pangalila, T. (2018, November). Emotional Quotient, Family Environment and Their Influences on Teacher Performance. In Annual Civic Education Conference (ACEC 2018). Atlantis Press. https://doi.org/10.2991/acec-18.2018.31.

Mahmuda. (2016). Pengembangan Pedoman in service Tranining pada Kurikulum 2013 Melalui KKG-PAI dalam Meningkatkan Profesionalisme Guru PAI di Kecamatan Panji Situbondo. Jurnal Pendidikan Agama Islam 1(1): 21-31. https://doi.org/10.35316/jpii.v1i1.34.

Masdudi. (2016). Pengembangan Kecerdasan Emosional Guru PAUD dalam Proses Pembelajaran. 
Awladi: Jurnal Pendidikan Anak 12(1): 123-132. https://doi.org/10.24235/awlady.v2i1.761.

Masrul. (2015). A Study of Students' Assessment in Writing Skills of the English Language. Jurnal Obsesi. 1(1), 65-73. https://obsesi.or.id/index.php/obsesi/article/view/57/56.

Mardapi, D., \& Herawan, T. (2018). Assessing teacher competence and its follow-up to support professional development sustainability. Journal of Teacher Education for Sustainability, 2O(1), 106. https://doi.org/10.2478/jtes-2018-0007.

McGrew, S., Breakstone, J., T. Ortega, M. Smith \& S. Wineburg. (2018). Can Students Evaluate Online Sources? Learning from Assessments of Civic Online Reasoning. Theory \& Research in Social Education. 46(2), 165-193. https://doi.org/10.1080/00933104.2017.1416320.

Paskaran, U. N., \& Azman, N. (2020). Emotional Quotient in Higher Education as a Case Study of Awareness in Malaysia. International Journal of Advanced Research in Education and Society, 2(3), 46-57. http://myjms.mohe.gov.my/index.php/ijares/article/view/11178.

Pisani, L., Borisova, I., \& Dowd, A. J. (2018). Developing and validating the international development and early learning assessment (IDELA). International Journal of Educational Research, 91, 1-15. https://doi.org/10.1016/j.ijer.2018.06.007.

Preś, J.E., Kurpisz \& Pełka-Wysiecka. (2018). What Regulates Gratitude Response of Women and Men? The Role of the Received Good, Psychosocial Factors, and Repayment. Psychological Reports 123(2), 395-419. https://doi.org/10.1177/o033294118811620.

Puspitacandri, A. (2020). The Effects of Intelligence, Emotional, Spiritual and Adversity Quotient on the Graduates Quality in Surabaya Shipping Polytechnic. European Journal of Educational Research, 9(3), 1075-1087. https://doi.org/10.12973/eu-jer.9.3.1075.

Rahmawati, R. F., Imaduddin, M., Haqiqi, A. K., Fikri, A. A., Fawaida, U., Prasetyo, D. R., \& Faikhamta, C. (2020). Assessing Psychosocial Outdoor Learning Environment of Pre-service Science Teachers through The Field Trip Experiences. Participatory Educational Research, 7(2), 135-150. https://doi.org/10.17275/per.20.24.7.2.

Richmond, G., M. Salazar, \& N. Jones. (2019). Assessment and the Future of Teacher Education. Journal of Teacher Education, 70(2), 86-89. https://doi.org/10.1177/0022487118824331.

Riduwan. (2014). Metode dan Teknik Menyusun Proposal Penelitian [Methods and Techniques of Preparing a Research Proposal]. Bandung: Penerbit Alfabeta.

Sahrani, S., Mufidah, N., \& Rusnadi, R. (2019). The implementation of language assessment principles on summative test at madrasah aliyah ni'matul aziz jelapat barito kuala academic year 2017/2018. LET: Linguistics, Literature and English Teaching Journal, 8(2), 322-342. http://dx.doi.org/10.18592/let.v8i2.4026.

Sudijono, A. (2014). Metode Penelitian Kombinasi [Mixed Research Method]. Bandung: Alfabeta.

Sugiyono. (2014). MetodePenelitian Pendidikan (Pendekatan Kuantitatif, Kualitatif, dan $R$ \& D) [Educational Research Methods (Quantitative, Qualitative, and $R$ \& D Approaches)]. Bandung: Alfabeta.

Sukenti, D,. Tambak, S., \& Charlina. (2020). Developing Indonesian language learning assessments: Strengthening the personal competence and Islamic psychosocial of teachers. International Journal of Evaluation and Research in Education. 9(4), 1079-1087. https://doi.org/10.11591/ijere.v9i4.20677.

Sukenti, D., \& Tambak, S. (2019). Strengthening Islamic Psychosocial and Self-confidence in Develophing Student Thinking Creative. ICOSEEH 2019, 4, 446-453. https://doi.org/10.5220/o009370404460453.

Supriyanto, A. S., Ekowati, V. M., \& Masyhuri, M. (2019). The relationship among spiritual intelligence, emotional intelligence, organizational citizenship behaviour, and employee performance. Etikonomi, 18(2), 249-258. http://doi.org/10.15408/etk.v18i2.11318.

Tambak, S., \& Sukenti, D. (2019). Strengthening Linguistic and Emotional Intelligence of Madrasah Teachers in Developing the Question and Answer Methods. Miqot: Jurnal Ilmu-Ilmu Keislaman, 43(1), 111-129. http://dx.doi.org/10.30821/miqot.v43i1.672.

Tambak, S., \& Sukenti, D. (2020). Strengthening Islamic Behavior and Islamic Psychosocial in Developing Professional Madrasah Teachers. Cakrawala Pendidikan: Jurnal Ilmiah Pendidikan, 39(1), 65-78. https://doi.org/10.21831/cp.v39i1.26001.

Tambak, S., Ahmad, M. Y., \& Sukenti, D. (2020). Strengthening Emotional Intelligence in Developing the Madrasah Teachers' Professionalism. Akademika: Journal of Southeast Asia Social Science and Humanities, 9o(2), 27-38. https://doi.org/10.17576/akad-2020-9002-03. 
Tambak, S., Amril, M., Khairi, Z., \& Sukenti, D. (2018). Development of Madrasah Teacher Professionalism by Strengthening the Khalifah Concept and Islamic Psychosocial Perspective. in International Conference on Islamic Education (ICIE 2018). Atlantis Press. https://doi.org/10.2991/icie-18.2018.7.

Tambak, S., Ahmad, M., Sukenti, D., \& Ghani, A. R. B. A. (2020). Profesionalisme Guru Madrasah: Internalisasi Nilai Islam dalam Mengembangkan Akhlak Aktual Siswa. Jurnal Pendidikan Agama Islam Al-Thariqah, 5(2), 79-96. https://doi.org/10.25299/althariqah.2020.vol5(2).5885.

Thoma, B., Turnquist, A., Zaver, F., Hall, A. K., \& Chan, T. M. (2019). Communication, learning and assessment: Exploring the dimensions of the digital learning environment. Medical teacher, 41(4), 385-390. https://doi.org/10.1080/0142159X.2019.1567911.

Tjalla, A. (2020). The Influence of the Prevention, Advocacy, Distribution, Repair, and Adjustment Functions of Teacher Guidance and Counselling on the Psychosocial Conditions, Self-Reliance, and Competence of High School Students in DKI Jakarta Province. International Journal of Education and Practice, 8(1), 174-189. http//doi.org/10.18488/journal.61.2020.81.174.189

Tuckman, B. W. (1999). Conducting Educational Research. Fort Wort, TX: Harcourt Brace College Publishers.

Utami, IGA L. P. Prestrigde, S. Saukah, A. \& Hamied, F. A. (2019). Continuing Professional Development and teachers' Perceptions and Practices-A Tenable Relationship. Indonesian Journal of Applied Linguistics, 9(1), 108-118. https://doi.org/10.17509/ijal.v9i1.12463.

Widiana, I. Wayan; Jampel, \& I. Nyoman. (2016). Learning Model and Form of Assesment toward the Inferensial Statistical Achievement by Controlling Numeric Thinking Skills. International Journal of Evaluation and Research in Education. 5(2), 135-147. http://doi.org/10.11591/ijere.v5i2.4532.

Wiersma, W. (2000). Research Methods in Education: An Intruductio. London: Allyn and Bacon.

$\mathrm{Xu}, \mathrm{Y} .$, \& Brown, G. T. (2016). Teacher assessment literacy in practice: A reconceptualization. Teaching and Teacher Education, 58, 149-162. https://doi.org/10.1016/j.tate.2016.05.010.

Zaid, C. M., Saputra, J., Ismail, Z., Othman, M. A. U., Ab Majid, M. R., \& Abdullah, N. A. C. (2020). The Nature of Psychosocial Environment in Arabic Classroom among Malaysian Public Universities. Journal of Talent Development and Excellence,12(3s), 2990-2998. http://www.iratde.com/index.php/jtde/article/view/1208. 